\title{
PENGARUH PROFITABILITAS TERHADAP NILAI PERUSAHAAN DENGAN KEBIJAKAN DIVIDEN SEBAGAI VARIABEL MODERASI PERUSAHAAN INDEKS KOMPAS 100
}

\author{
I Wayan Edi Suliastawan ${ }^{1}$ \\ Ni Ketut Purnawati \\ ${ }^{1,2}$ Fakultas Ekonomi dan Bisnis Universitas Udayana, Bali, Indonesia \\ email: suliastawanedi@gmail.com
}

\begin{abstract}
ABSTRAK
Nilai perusahaan dapat memberikan kemakmuran pemegang saham secara maksimum apabila kinerja baik. salah satunya dapat diukur dengan profitabilitas dan faktor lain yang mempengaruhi nilai perusahaan adalah kebijakan dividen. Tujuan penelitian ini ialah untuk mengetahui pengaruh profitabilitas terhadap nilai perusahaan dengan kebijakan deviden sebagai variabel moderasi pada perusahaan Indeks Kompas 100. Penelitian ini dilakukan di seluruh perusahaan pertambangan yang tergabung dalam Indeks Kompas 100 di Bursa Efek Indonesia (BEI). Jumlah sampel, dengan menggunakan metode purposive sampling ialah sebanyak 17 perusahaan dari 100 perusahaan selama periode 2014-2018. Teknik analisis data yang diterapkan dalam penelitian ini adalah moderasi regresi analisis. Hasil analisis menghasilkan, profitabilitas berpengaruh positif signifikan terhadap nilai perusahaan. Kebijakan deviden berpengaruh positif signifikan terhadap nilai perusahaan. Kebijakan deviden memoderasi pengaruh profitabilitas terhadap nilai perusahaan pada sektor pertambangan Indeks Kompas 100.

Kata kunci : profitabilitas, kebijakan deviden dan nilai perusahaan.
\end{abstract}

\begin{abstract}
The value of the company can provide maximum shareholder prosperity if the performance is good. one of them can be measured by profitability and other factors that influence company value are dividend policy. The purpose of this study was to determine the effect of profitability on firm value with dividend policy as a moderating variable in the Kompas 100 Index company. This research was conducted in all mining companies incorporated in the Kompas 100 Index on the Indonesia Stock Exchange (IDX). The number of samples, using the purposive sampling method is as many as 17 companies from 100 companies during the 2014-2018 period. The data analysis technique applied in this study is the regression analysis moderation. The results of the analysis produce, profitability has a significant positive effect on firm value. Dividend policy has a significant positive effect on firm value. Dividend policy moderates the effect of profitability on company value in the mining sector of the Kompas 100 Index.

Keyword : profitability, dividend policy and company value.
\end{abstract}




\section{PENDAHULUAN}

Persaingan menuntut perusahaan-perusahaan untuk menempatkan dirinya dalam posisi yang stabil dan siap bersaing sehingga dapat meningkatkan nilai perusahaan dan dapat menjadi pertimbangan khusus bagi para investor dalam menanamkan modalnya (Mirah et al., 2014). Nilai perusahaan berbanding lurus dengan tujuan perusahaan untuk meningkatkan laba dari waktu ke waktu sebagai suatu ukuran kinerja perusahaan dan sebagai sarana untuk memberikan pengaruh terhadap persepsi investor pada perusahaan (Diani, 2015).

Tujuan manajemen keuangan adalah memaksimumkan nilai perusahaan. Nilai perusahaan merupakan kondisi yang menggambarkan pencapaian suatu perusahaan selama proses beroperasinya (Aries, 2011:87). Peningkatan nilai perusahaan dipandang sebagai suatu prestasi yang mencerminkan peningkatan kemakmuran bagi pemegang saham (Triana \& Istyana, 2017). Kemakmuran pemegang saham dapat tercermin dari keuntungan yang diperoleh dari per lembar saham yang diinvestasikannya. Nilai perusahaan yang tinggi menjadi keinginan para pemegang saham (Puspitaningtyas, 2017). Nilai perusahaan direpresentasikan dengan nilai pasar dari saham. Artinya, bahwa tingginya nilai pasar dari saham mencerminkan tingginya nilai perusahaan, dan sebaliknya (Cheryta et al., 2017).

(Aries, 2011:91) mengatakan bahwa nilai perusahaan merupakan hasil kerja manajemen dari beberapa dimensi, yakni arus kas bersih dari keputusan investasi, pertumbuhan, dan biaya modal perusahaan. Bagi investor, nilai perusahaan merupakan konsep penting, karena nilai perusahaan merupakan indikator bagaimana pasar menilai perusahaan secara keseluruhan. Nilai perusahaan yang tinggi menjadi keinginan pemilik perusahaan, nilai tinggi menunjukkan kemakmuran pemegang saham juga tinggi. Nilai perusahaan dapat dipengaruhi oleh kebijakan dividen, kebijakan utang dan profitabilitas. (Napa J. Awat, 2000:112) mengemukakan bahwa nilai perusahaan dipengaruhi oleh kebijakan utang dan profitabilitas. Nilai perusahaan dipengaruhi oleh kebijakan dividen dan profitabilitas. Enterprise Value (EV) atau dikenal juga sebagai firm value (nilai perusahaan) merupakan konsep penting bagi investor, karena merupakan indikator bagi pasar menilai perusahaan secara keseluruhan. Nilai perusahaan merupakan harga yang bersedia dibayar oleh calon pembeli jika perusahaan tersebut dijual. Nilai perusahaan merupakan cerminan dari penambahan dari jumlah ekuitas perusahaan dengan utang perusahaan, dimana hak pemilik atas aktiva perusahaan yang merupakan kekayaan bersih (jumlah aktiva dikurangi kewajiban) (Andawasatya et al., 2017). Optimalisasi nilai perusahaan dapat dicapai melalui pelaksanaan fungsi manajemen keuangan di mana satu keputusan keuangan yang diambil akan mempengaruhi keputusan keuangan lainnya dan berdampak pada nilai perusahaan (Brigham \& Joel F. Houston, 2011:75). Manajemen keuangan menyangkut penyelesaian atas keputusan penting yang diambil perusahaan, antara lain keputusan investasi, keputusan pendanaan, dan kebijakan dividen. Suatu kombinasi yang optimal atas ketiganya akan memaksimumkan nilai perusahaan yang selanjutnya akan meningkatkan kemakmuran kekayaan pemegang saham (Setyowati, 2014). 
Pemegang saham akan cenderung memaksimalkan nilai saham dan memaksa manajer untuk bertindak sesuai dengan kepentingan mereka melalui pengawasan yang mereka lakukan. Pentingnya nilai perusahaan karena dapat memberikan kemakmuran pemegang saham secara maksimum apabila harga saham perusahaan meningkat. Semakin tinggi harga saham, maka makin tinggi kemakmuran pemegang saham. Untuk mencapai nilai perusahaan umumnya para pemodal menyerahkan pengelolaannya kepada para professional (Gumanti, 2013:91). (Brigham \& Joel F. Houston, 2011) menjelaskan bahwa enterprise value (EV) atau dikenal juga sebagai firm value (nilai perusahaan) merupakan konsep penting bagi investor, karena merupakan indikator bagi pasar menilai perusahaan secara keseluruhan.

Profitabilitas merupakan kemampuan suatu perusahaan dalam memperoleh laba. Laba perusahaan tersebut akan menjadi acuan dalam pembayaran dividen. (Suad Husnan, 2015:118) profitabilitas adalah kemampuan suatu perusahaan dalm menghasilkan keuntungan pada tingkat penjualan, aset dan modal saham tertentu. Profitabilitas menggambarkan kemampuan badan usaha untuk menghasilkan laba dengan menggunakan seluruh modal yang dimiliki. Profitabilitas penting dalam usaha mempertahankan kelangsungan hidupnya dalam jangka panjang, karena profitabilitas menunjukkan apakah badan usaha tersebut mempunyai prospek yang baik di masa yang akan datang. Setiap badan usaha akan selalu berusaha meningkatkan profitabilitasnya, karena semakin tinggi tingkat profitabilitas suatu badan maka kelangsungan hidup badan usaha tersebut akan lebih terjamin. Besarnya tingkat laba akan mempengaruhi besarnya tingkat pembayaran dividen yang dibagikan kepada pemegang saham (Natalia, 2013). Profitabilitas juga mencerminkan keadaan posisi keuangan perusahaan. Hal ini menjadi perhatian utama investor dalam mengukur laba atas investasi yang dilakukan. (Yulandani et al., 2018).

(Brigham \& Joel F. Houston, 2011:67), profitabilitas adalah hasil akhir dari sejumlah kebijakan dan keputusan yang dilakukan oleh perusahaan. Apabila profitabilitas perusahaan baik, maka kreditur, supplier, dan juga investor akan melihat sejauh mana perusahaan dapat menghasilkan laba dari penjualan dan investasi perusahaan.

Beberapa penelitian menyatakan profitabilitas memiliki pengaruh positif dalam meningkatkan nilai perusahaan. Penelitian (Mery, 2017) menyatakan profitabilitas secara langsung memiliki pengaruh positif terhadap nilai perusahaan. (Sisca, 2016) membuktikan profitabilitas memiliki pengaruh positif dalam meningkatkan nilai perusahaan. (Alamsyah, 2017) menyatakan peningkatan profitabilitas memiliki pengaruh positif terhadap nilai perusahaan. (Tahu \& Susilo, 2017) membuktikan hal yang sama dimana profitabilitas memiliki pengaruh positif dalam meningkatkan nilai perusahaan. Berbeda halnya dengan penelitian (Triana \& Istyana, 2017) menyatakan bahwa profitabilitas tidak berpengaruh terhadap nilai perusahaan. (Sucuahi \& Cambarihan, 2016) membuktikan dalam penelitiannya profitabilitas tidak berpengaruh secara langsung terhadap nilai perusahaan.

(Arthur J. Keown, 2011:65) menjelaskan selain profitabilitas, nilai perusahaan dapat dilihat dari kemampuan perusahaan membayar dividen. (Sundari \& Utami, 2013) menyatakan dividen adalah proporsi laba yang dibagikan kepada 
para pemegang saham dalam jumlah yang sebanding dengan jumlah lembar saham yang dimiliknya. (Hanafi, 2015:83) menyatakan terlihat dari sisi investor, dividen merupakan salah satu faktor yang mempengaruhi peningkatan pemberian dana di pasar modal. Banyak perusahaan menjalankan kebijakan pembayaran dividen yang stabil, artinya jumlah dividen per lembar yang dibayarkan setiap tahunnya relatif tetap selama jangka waktu tertentu meskipun pendapatan per lembar saham per tahunnya berfluktuasi. Pembayaran dividen yang stabil ini dapat memberikan kesan kepada investor bahwa perusahaan tersebut mempunyai prospek yang baik di masa datang (Setiyawati et al., 2018). Sedangkan kebijakan dividen berkaitan dengan kebijakan mengenai seberapa besar laba yang diperoleh perusahaan akan didistribusikan kepada pemegang saham (Murukefu \& Ouma, 2017).

Kebijakan dividen sangat penting karena mempengaruhi kesempatan investasi perusahaan, harga saham, struktur finansial, arus pendanaan dan posisi likuiditas. Kebijakan dividen sebagai variabel pemoderasi pengaruh kinerja keuangan terhadap nilai perusahaan, hal ini dikarenakan kebijakan dividen menjadi pusat perhatian banyak pihak seperti pemegang saham, kreditor, maupun pihak eksternal lain yang memiliki kepentingan dari informasi yang dikeluarkan perusahaan (Ajanthan, 2013). Pemberian dividen oleh perusahaan, membuat perusahaan dianggap telah memenuhi kewajibannya kepada investor. Apabila dividen yang diberikan perusahaan tinggi, maka dianggap perusahaan tersebut memiliki kinerja yang baik (Borges Forti et al., 2015). Kebijakan pembayaran dividen yang dilakukan oleh perusahaan, secara tersirat diatur dalam konflik keagenan anatara manajemen (agent) dan pemegang saham (principal). Kebijakan pembayaran dividen merupakan salah satu keputusan penting yang dilakukan oleh perusahaan, karena berkaitan dengan rencana investasi perusahaan di masa yang akan datang. Rencana investasi yang dimaksudkan mengenai jumlah laba bersih yang akan dibagikan sebagai dividen dan jumlah laba bersih yang akan diinvestasikan kembali dalam bentuk laba ditahan. (Setiyawati et al., 2018)), menyatakan bahwa keputusan perusahaan tersebut dapat dicapai melalui pelaksanaan fungsi manajemen keuangan yang dilakukan dengan hati - hati dan tetap, karena keputusan keuangan yang diambil akan mempengaruhi keputusan keuangan lainnya dan akan berdampak terhadap nilai perusahaan.

Keputusan keuangan yang harus dipertimbangkan dengan baik adalah keputusan investasi, keputusan pendanaan dan kebijakan dividen (Labhane \& Das, 2015). Keputusan dividen menyangkut tentang masalah distribusi dari laba yang diperoleh perusahaan, apakah sebaiknya dibagikan kepada pemegang saham dalam bentuk dividen atau laba tersebut sebaiknya diinvestasikan kembali (reinvestment) atau ditahan oleh perusahaan dalam bentuk laba ditahan (Ghalandari, 2013). Besar kecilnya dividen ini merupakan trade off antara porsi keuntungan yang akan dibayarkan sebagai dividen dan porsi keuntungan yang akan tetap ditahan di dalam perusahaan sebagai bagian dari komponen internal financing. Laba ditahan merupakan salah satu sumber dana yang paling penting dalam pertumbuhan perusahaan karena dapat digunakan untuk membiayai operasi perusahaan selanjutnya (Suteja \& Abas, 2018). Rasio pembayaran dividen (dividend pay out ratio) menentukan jumlah laba yang ditahan dan harus dinilai dalam hubungannya 
dengan sasaran untuk memaksimumkan nilai perusahaan (Teguh \& Ardianto, 2015).

Terdapat beberapa teori yang berkenaan dengan pengaruh antara kebijakan dividen dengan nilai perusahaan, di antaranya adalah teori ketidakrelevanan dividen (dividend irrelevance theory) dan teori bird-in-the hand, yang keduanya saling bertentangan. Berdasarkan dividend irrelevance theory yang dianjurkan oleh (Miller dan Modigliani dalam (Sundari \& Utami, 2013) menyatakan bahwa kebijakan dividen tidak mempunyai pengaruh baik terhadap nilai perusahaan, maupun biaya modalnya. Mereka berpendapat bahwa nilai suatu perusahaan hanya akan ditentukan oleh kemampuan dasarnya untuk menghasilkan laba serta risiko bisnisnya. Nilai suatu perusahaan tergantung semata-mata pada pendapatan yang dihasilkan oleh aktivanya, bukan pada bagaimana pendapatan tersebut dibagi diantara dividen dan laba ditahan. Berbeda dengan dividend irrelevance theory, teori bird-in-the hand yang diajukan oleh (Brigham \& Joel F. Houston, 2011:118), nilai perusahaan akan dimaksimumkan oleh rasio pembayaran dividen yang tinggi, karena investor menganggap bahwa risiko dividen tidak sebesar kenaikan biaya modal, sehingga investor lebih menyukai keuntungan dalam bentuk dividen daripada keuntungan yang diharapkan dari kenaikan nilai modal.

Beberapa penelitian menyatakan kebijakan dividen memiliki keterkaitan dengan profitabilitas terhadap nilai perusahaan. Penelitian (Diani, 2015) menyatakan kebijakan dividen mampu memoderasi pengaruh positif profitabilitas terhadap nilai perusahaan. (Burhanudin \& Nuraini, 2018) menyatakan kebijakan dividen memoderasi pengaruh positif profitabilitas terhadap nilai perusahaan. (Mery, 2017) menyatakan profitabilitas berpengaruh positif terhadap nilai perusahaan diperkuat atau dimoderasi oleh variabel kebijakan dividen. (Sisca, 2016) menyatakan sebagai variabel moderasi kebijakan dividen mampu memperkuat pengaruh profitabilitas terhadap nilai perusahaan secara positif. Berdasarkan beberapa hasil kontradiksi dengan beberapa penelitian sebelumnya maka dibutuhkan penelitian lebih lanjut mengenai pengaruh profitabilitas terhadap nilai perusahaan dengan kebijakan dividen sebagai variabel moderasi pada perusahaan Indeks Kompas 100 tahun 2014-2018.

Berdasarkan latar belakang di atas, dapat dinyatakan rumusan masalah sebagai berikut: Apakah profitabilitas berpengaruh signifikan terhadap nilai perusahaan pada perusahaan Indeks Kompas 100 periode 2014-2018? Apakah kebijakan dividen berpengaruh signifikan terhadap nilai perusahaan pada perusahaan Indeks Kompas 100 periode 2014-2018? Apakah kebijakan dividen memoderasi pengaruh profitabilitas terhadap nilai perusahaan pada perusahaan Indeks Kompas 100 periode 2014-2018? Berdasarkan pokok permasalahan yang telah diuraikan sebelumnya, maka tujuan dari penelitian ini adalah: Untuk menganalisis pengaruh profitabilitas terhadap nilai perusahaan pada perusahaan Indeks Kompas 100 periode 2014-2018, Untuk menganalisis pengaruh kebijakan dividen terhadap nilai perusahaan pada perusahaan Indeks Kompas 100 periode 2014-2018, Untuk menganalisis kebijakan dividen memoderasi pengaruh profitabilitas terhadap nilai perusahaan pada perusahaan Indeks Kompas 100 periode 2014-2018. Berdasarkan tujuan penelitian, maka penelitian ini diharapkan memberikan manfaat secara teoritis maupun praktis yaitu sebagai berikut: 
Penelitian ini diharapkan dapat memberikan tambahan pengetahuan dan pemahaman mengenai pengaruh profitabilitas terhadap nilai perusahaan dengan kebijakan dividen. Kegunaan praktis penelitian ini bagi perusahaan dapat memberikan sumbangan pemikiran mengenai pentingnya membayarkan dividen untuk memberikan sinyal mengenai keberhasilan perusahaan dalam membukukan nilai perusahaan sebagai pelaporan kepada pemegang saham.

Teori sinyal menekankan kepada pentingnya informasi yang dikeluarkan oleh perusahaan terhadap keputusan investasi pihak luar perusahaan. Hal ini menyatakan bahwa manajemen selalu mengungkapkan informasi yang diinginkan oleh investor, khususnya apabila informasi tersebut ada berita baik (good news). Informasi mengenai perusahaan merupakan sinyal bagi investor dalam keputusan berinvestasi (Brigham \& Joel F. Houston, 2011:76). Signalling theory adalah informasi mengenai perusahaan merupakan sinyal bagi investor, dalam keputusan berinvestasi. Tujuan dari teori Signalling adalah menaikkan nilai suatu perusahaan saat melakukan penjualan saham. Sinyal dapat berupa informasi bersifat financial maupun non-financial yang menyatakan bahwa perusahaan tersebut lebih baik daripada perusahaan lain. Perusahaan yang berkualitas baik dengan sengaja akan memberikan sinyal pada pasar, sehingga pasar diharapkan dapat membedakan perusahaan yang berkualitas baik dan buruk. Agar sinyal tersebut efektif, maka harus dapat ditanggapi oleh pasar dan dipersepsikan baik, serta tidak mudah ditiru oleh perusahaan yang berkualitas buruk (Harnanto, 2012:87). Menurut (Allen dan Faulhaber dalam (Sucuahi \& Cambarihan, 2016), perusahaan yang berkualitas buruk tidak mudah untuk meniru perusahaan yang berkualitas baik yang melakukan underpricing, hal ini disebabkan karena cash flow periode berikutnya akan mengungkapkan tipe perusahaan tersebut (baik atau buruk). Sinyal yang baik adalah yang tidak dapat ditiru oleh perusahaan yang nilai perusahaanya lebih rendah karena faktor biaya.

Teori agency approach theory merupakan dasar yang digunakan untuk memahami corporate governance. Teori keagenan menyangkut hubungan kontraktual antara anggota-anggota di perusahaan. (Jensen dan Meckling dalam (Diani, 2015) menjelaskan bahwa hubungan agensi terjadi ketika satu orang atau lebih (principal) mempekerjakan orang lain (agent) untuk memberikan suatu jasa dan kemudian mendelegasikan wewenang pengambilan keputusan. Yang disebut principal adalah pemegang saham atau investor dan yang dimaksud agent adalah manajemen yang mengelola perusahaan. Inti dari hubungan keagenan adalah adanya pemisahan fungsi antara kepemilikan di pihak investor dan pengendalian di pihak manajemen

Konsep agency approach theory menurut (Anthony dan Govindarajan dalam (Natalia, 2013) adalah hubungan atau kontak antara principal dan agent. Principal mempekerjakan agent untuk melakukan tugas untuk kepentingan principal, termasuk pendelegasian otorisasi pengambilan keputusan dari principal kepada agent. Pada perusahaan yang modalnya terdiri atas saham, pemegang saham bertindak sebagai principal, dan CEO (Chief Executive Officer) sebagai agent mereka.

Struktur modal disusun untuk mengurangi konflik antar berbagai kelompok kepentingan. Konflik antara pemegang saham dengan manager adalah konsep free 
cash flow. Ada kecenderungan manajer ingin menahan sumber daya sehingga mempunyai kontrol atas sumber daya tersebut. Hutang bisa dianggap sebagai cara untuk mengurangi konflik keagenan free cash flow. Jika perusahaan menggunakan hutang, maka manajer akan dipaksa untuk mengeluarkan kas dari perusahaan untuk membayar bunga.

Signalling Theory, (Diani, 2015) menyatakan bahwa profitabilitas mengukur kemampuan perusahaan dalam menghasilkan keuntungan dari kegiatan bisnis yang dilakukan. Hasilnya, investor dapat melihat seberapa efisien perusahaan menggunakan aset dan dalam melakukan operasinya untuk menghasilkan keuntungan. Profitabilitas adalah gambaran dari kinerja manajemen dalam mengelola perusahaan. Ukuran profitabilitas perusahaan dapat berbagai macam seperti laba operasi, laba bersih, tingkat pengembalian invetasi/aktiva, dan tingkat pengembalian ekuitas pemilik.

Beberapa penelitian menyatakan profitabilitas memiliki pengaruh positif dalam meningkatkan nilai perusahaan. Penelitian (Mery, 2017) menyatakan profitabilitas secara langsung memiliki pengaruh positif terhadap nilai perusahaan. (Sisca, 2016) membuktikan profitabilitas memiliki pengaruh positif dalam meningkatkan nilai perusahaan. (Alamsyah, 2017) menyatakan peningkatan profitabilitas memiliki pengaruh positif terhadap nilai perusahaan. (Tahu \& Susilo, 2017) membuktikan hal yang sama dimana profitabilitas memiliki pengaruh positif dalam meningkatkan nilai perusahaan. Berdasarkan hasil penelitian tersebut maka dapat dirumuskan hipotesis penelitian sebagai berikut. Berdasarkan kajian teori dan data empiris maka dirumuskan hipotesis sebagai berikut:

$\mathrm{H}_{1}$ : profitabilitas berpengaruh positif signifikan terhadap nilai perusahaan.

Berdasarkan signalling theory, kebijakan dividen sering dianggap sebagai signal bagi investor dalam menilai baik buruknya perusahaan, hal ini disebabkan karena kebijakan dividen dapat membawa pengaruh terhadap harga saham perusahaan (Weston dan Copeland dalam (Sundari \& Utami, 2013). Perusahan yang yang mempunyai DPR yang tinggi belum tentu memberikan dividen yang besar, karena perusahaan mungkin akan menggunakan hasil labanya yang akan digunakan sebagai tambahan modal untuk memutar kegiatan perusahaan (Mery, 2017). Apabila dividen yang dibayarkan tinggi maka harga saham cenderung tinggi sehingga nilai perusahaan juga tinggi. Namun, jika dividen yang dibayarkan kepada pemegang saham kecil maka harga saham perusahaan itu juga rendah. Dengan demikian, dividen yang besar akan meningkatkan nilai perusahaan.

Beberapa penelitian menyatakan kebijakan dividen memiliki keterkaitan dengan profitabilitas. Penelitian (Diani, 2015) menyatakan kebijakan dividen berpengaruh terhadap nilai perusahaan. Burhanudin dan (Burhanudin \& Nuraini, 2018) menyatakan kebijakan dividen secara positif berpengaruh terhadap nilai perusahaan. (Mery, 2017) menyatakan kebijakan dividen berpengaruh positif terhadap nilai perusahaan. (Sisca, 2016) menyatakan kebijakan dividen secara positif berpengaruh terhadap nilai perusahaan. Berdasarkan kajian teori dan data empiris maka dirumuskan hipotesis sebagai berikut :

$\mathrm{H}_{2}$ : kebijakan dividen berpengaruh positif signifikan terhadap nilai perusahaan.

Pembayaran dividen menunjukkan bahwa perusahaan tersebut memiliki kinerja perusahaan yang baik. Dividen payout ratio yang tinggi akan memperkuat 
pengaruh profitabilitas terhadap nilai perusahaan. Kebijakan dividen bertindak sebagai moderasi yang memperkuat pengaruh profitabilitas terhadap nilai perusahaan. Berdasarkan signalling theory menyatakan profitabilitas yang tinggi serta kebijakan dividen yang optimal mampu mencerminkan prospek perusahaan yang bagus sehingga dapat menaikkan harga saham serta meningkatkan nilai perusahaan (Mery, 2017). (Burhanudin \& Nuraini, 2018) menjelaskan pasar cenderung menginterpertasikan pembayaran dividen sebagai sinyal tentang prospek cerah perusahaan di masa mendatang sehingga dengan pembayaran dividen kepada pemegang saham, laba yang diperoleh perusahaan, diprediksikan oleh investor akan berlanjut atau bahkan akan semakin baik. Semakin baik prospek perusahaan maka perusahaan dianggap menguntungkan oleh investor, akibatnya harga saham perusahaan tersebut akan meningkat karena diminati para investor. Harga saham yang tinggi mencerminkan nilai perusahaan yang tinggi (Ajanthan, 2013).

Penelitian (Mery, 2017) menyatakan profitabilitas berpengaruh positif terhadap nilai perusahaan diperkuat atau dimoderasi oleh variabel kebijakan dividen. (Sisca, 2016) menyatakan sebagai variabel moderasi kebijakan dividen mampu memperkuat pengaruh profitabilitas terhadap nilai perusahaan secara positif. (Diani, 2015) menyatakan kebijakan dividen mampu memoderasi pengaruh positif profitabilitas terhadap nilai perusahaan. (Burhanudin \& Nuraini, 2018) menyatakan kebijakan dividen memoderasi pengaruh positif profitabilitas terhadap nilai perusahaan. Berdasarkan kajian teori dan data empiris maka dirumuskan hipotesis sebagai berikut :

$\mathrm{H}_{3}$ : kebijakan dividen memoderasi pengaruh profitabilitas terhadap kebijakan dividen.

Kerangka konseptual merupakan hubungan logis dari landasan teori dan kajian empiris. Kerangka konseptual menunjukkan pengaruh antar variabel dalam penelitian. Kerangka konseptual dalam penelitian ini disajikan pada Gambar 1 berikut ini

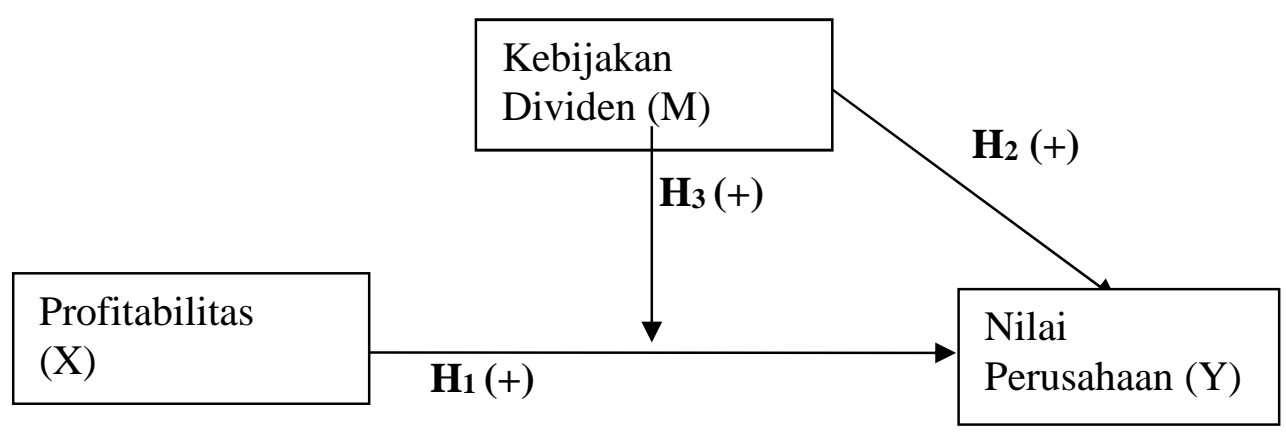

Gambar 1. Kerangka Konseptual

Sumber: Data Diolah, 2018

\section{METODE PENELITIAN}

Desain penelitian ini diukur berdasarkan permasalahan yang diteliti, penelitian ini digolongkan pada penelitian asosiatif (hubungan), yaitu penelitian yang bertujuan untuk mengetahui hubungan dari variabel atau lebih (Sugiyono, 2013 :5). Ruang lingkup wilayah penelitian ini dilakukan di seluruh perusahaan 
yang tergabung dalam Indeks Kompas 100 di Bursa Efek Indonesia (BEI) periode 2014 - 2018 dengan mengambil data melalui situs resmi BEI (www.idx.co.id). Alasan dipilihnya lokasi ini karena saham dalam Indeks Kompas 100 memiliki likuiditas yang tinggi, nilai kapitalisasi yang besar dan juga merupakan sahamsaham yang memiliki fundamental dan kinerja yang baik. Obyek dari penelitian ini adalah nilai perusahaan pada Indeks Kompas 100 di Bursa Efek Indonesia (BEI) periode 2014 - 2018.

Variabel dalam penelitian ini terdiri dari variabel dependen $(\mathrm{Y})$, variabel independen $(\mathrm{X})$ dan variabel moderasi. Variabel dependen dalam penelitian ini adalah nilai perusahaan (Y). Variabel independen dalam penelitian ini adalah profitabilitas (X). Variabel moderasi dalam penelitian ini adalah kebijakan Dividen (M). Dalam penelitian ini rasio keuangan yang dapat digunakan untuk mengukur nilai perusahaan adalah Price Book To Share (PBV). Rasio ini membandingkan antara harga pasar per lembar saham (market price per share) dengan nilai buku per lembar saham. PBV dalam penelitian inimenunjukkan tingkat kemampuan mengukur nilai perusahaan yang dihimpun dalam periode tahun 2014 hingga 2018 dari data Indonesian Capital Market Directory (ICMD) pada sektor perperusahaan manufakturan di Bursa Efek Indonesia. Menurut (Diani, 2015) Rasio ini dapat di rumuskan sebagai berikut:

$$
P=\frac{S \quad P}{B \quad V}
$$

Profitabilitas adalah kemampuan perusahaan untuk menghasilkan keuntungan pada tingkat penjualan, aset dan modal tertentu. Investor jangka panjang akan sangat berkepentingan dengan analisis profitabilitas ini, misalnya bagi pemegang saham, pemegang saham akan melihat keuntungan yang benarbenar akan diterima dalam bentuk dividen. Dalam penelitian ini, profitabilitas diukur dengan ROA (Return On Asset), rasio ini mengukur kemampuan perusahaan dalam memperoleh keuntungan (laba) secara keseluruhan dalam periode tahun 2014 hingga 2018 dari data Indonesia Capital Market Directory (ICMD) pada sektor manufaktor di Bursa Efek Indonesia. Menurut (Brigham \& Joel F. Houston, 2011) Rasio ini dapat dirumuskan sebagai berikut:

$$
R \quad O A \text { si }=\frac{N \text { In }}{T \text { A }} \times 100 \% \text {. }
$$

Kebijakan dividen adalah pembagian keuntungan yang diberikan perusahaan penerbit saham tersebut atas keuntungan yang dihasilkan perusahaan. Kebijakan dividen dalam penelitian ini diwakili oleh Dividend Payout Ratio. Data yang digunakan adalah laporan keuangan pada perusahaan manufakur yang secara berturut-turut membagikan dividendalam periode tahun 2014 hingga 2018 dari data Indonesia Capital Market Directory (ICMD) pada sektor manufaktur di Bursa Efek Indonesia. (Arthur J. Keown, 2011), dividend payout ratio adalah jumlah dividen relatif terhadap net income perusahaan atau earning per share. (Mirah et al., 2014) dividend payout ratio merupakan rasio yang menunjukkan persentase laba perusahaan yang dibayarkan kepada pemegang saham biasa perusahaan berupa dividen kas. Menurut (Gumanti, 2013) Rasio ini dapat dirumuskan sebagai berikut:

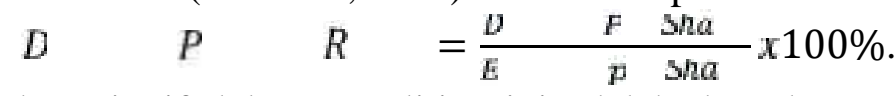

Data kuantitatif dalam penelitian ini adalah data-data mengenai kebijakan dividen, profitabilitas dan nilai perusahaan yang didapatkan dari laporan keuangan 
tahunan perusahaan di Indeks Kompas 100 selama periode 2014-2018 yang terdaftar di BEI. Data ini diperoleh dari situs resmi Bursa Efek Indonesia seperti: www.idx.co.id.

Populasi dalam penelitian ini adalah seluruh perusahaan yg terdaftar di Indeks Kompas 100 periode 2014-2018. Sampel Tehnik sampling yang diggunakan purposive sampling yaitu teknik penentuan sampel dengan pertimbangan tertentu: perusahaan yang secara konsisten tergabung dalam perusahaan Indeks Kompas 100 periode 2014-2018. Dari 100 sampel perusahaan yang tergabung dalam Indeks Kompas 100 periode 2014-2018 yang akan diteliti adalah 17 perusahaan.

Metode pengumpulan data yang digunakan dalam penelitian ini adalah observasi non partisipan. Pengumpulan data dilakukan dengan cara membaca, mencatat serta mempelajari uraian-uraian dari buku-buku, karya ilmiah berupa skripsi, Indonesian Capital Market Directory, serta situs-situs internet yang relevan. Teknik analisis data yang diterapkan dalam penelitian ini dilakukan secara kuantitatif dengan penekanan data yang bersumber dari data primer, yang mana data tersebut akan diolah kemudian dianalisis. Di samping itu, analisis data akan dilakukan secara kuantitatif dengan menerapkan landasan teori sehingga diharapkan akan memperoleh kesimpulan yang berbobot ilmiah.

Setelah data-data yang dibutuhkan diperoleh, selanjutnya dilakukan analisis sehingga data tersebut lebih berarti. Teknik perhitungan dan analisis data menggunakan Moderating Regression Analysis. Moderating Regression Analysis dinyatakan dalam bentuk regresi berganda dengan persamaan mirip regressi polynomial yang menggambarkan pengaruh nonlinier (Ghozali, 2016:47) yang dinyatakan dalam bentuk model persamaan sebagai berikut.

$$
\mathrm{Y}=\alpha+\beta_{1} \mathrm{X}+\beta_{2} \mathrm{M}+\beta_{3}(\mathrm{XM})+\mathrm{e}
$$

Keterangan:

$$
\begin{aligned}
& \mathrm{Y}=\text { nilai perusahaan } \\
& \alpha \quad=\text { konstanta } \\
& \beta_{1}, \beta_{2}, \beta_{3}, \quad=\text { koefisien regresi moderasi masing-masing variabel } \\
& \mathrm{X}=\text { profitabilitas } \\
& \mathrm{M} \quad=\text { kebijakan Dividen } \\
& \text { e } \quad=\text { error term yaitu faktor kesalahan dalam penelitian }
\end{aligned}
$$

\section{HASIL DAN PEMBAHASAN}

Hasil dari deskriptif data penelitian dari variabel profitabilitas, kebijakan deviden terhadap nilai perusahaan pada sektor pertambangan yang terdaftar di Indeks Kompas 100 di Bursa Efek Indonesia Periode 2014-2018 disajikan dalam Tabel dibawah.

Tabel 1. dapat dilihat bahwa variabel profitabilitas (X) memiliki nilai minimum sebesar 0,530 yang berarti nilai profitabilitas paling rendah 0,530 persen, nilai maksimum sebesar 4,640 persen, rata - rata tingkat profitabilitas sebesar 1,84656 persen, dengan rata - rata variasi dari profitabilitas sebesar 0,737735 . Variabel kebijakan deviden (M) memiliki nilai minimum sebesar 3,210 persen, nilai maksimum sebesar 63,970 persen, rata - rata tingkat kebijakan dividen sebesar 
17,44499 persen, dengan rata - rata variasi dari kebijakan dividen sebesar 09,249348 .

Tabel 1.

Hasil Uji Statistik Deskriptif

\begin{tabular}{lccccc}
\hline Variabel & N & Min. & Max. & Mean & Std. Deviasi \\
\hline Profitabilitas & 85 & 0,530 & 4,640 & 1,84656 & 0,737735 \\
$\begin{array}{l}\text { Kebijakan Deviden } \\
\begin{array}{l}\text { Profitabilitas-kebijakan } \\
\text { deviden }\end{array}\end{array}$ & 85 & 3,210 & 63,970 & 17,44499 & 9,249348 \\
$\begin{array}{l}\text { Nilai Perusahaan } \\
\text { S }\end{array}$ & 85 & 0,011 & 1,752 & 0,43719 & 0,374164 \\
\hline
\end{tabular}

Sumber: Data diolah, 2019

Variabel profitabilitas (X) - kebijakan deviden (M) memiliki nilai minimum sebesar 2,600 persen, nilai maksimum sebesar 201,506 persen, rata - rata tingkat profitabilitas - kebijakan dividen sebesar 35,85979 persen, dengan rata - rata variasi dari profitabilitas - kebijakan dividen sebesar 32,582177. Variabel nilai perusahaan (Y) memiliki nilai minimum sebesar 0,011 persen, nilai maksimum sebesar 1,752 persen, rata - rata tingkat nilai perusahaan sebesar 0,43719 persen, dengan rata - rata variasi dari nilai perusahaan sebesar 0,374164.

Uji normalitas bertujuan untuk menguji apakah dalam residual dari model regresi yang dibuat berdistribusi normal ataukah tidak. Metode yang digunakan dalam penelitian ini adalah metode statistik Kolmogorov-Smirnov, Alat uji yang biasa disebut K-S ini dapat dilakukan dengan melihat normal probability plot dan dengan melihat signifikansi dari tabel hasil uji $(\mathrm{P}>0,05)$.

Tabel 2.

Hasil Uji Normalitas Data dengan Uji Statistik Kolmogorov-Smirnov

\begin{tabular}{llr}
\hline & & \multicolumn{2}{c}{$\begin{array}{c}\text { Unstandardized } \\
\text { Residual }\end{array}$} \\
\hline $\mathrm{N}$ & Mean & 85 \\
Normal Parameters ${ }^{\mathrm{a}, \mathrm{b}}$ & Std. Deviation & .0000000 \\
Most Extreme Differences & Absolute & .349662742 \\
& Positif & .135 \\
Kolmogorov-Smirnov Z & Negatif & .135 \\
Asymp. Sig. (2-tailed) & & -.094 \\
\hline Sumber : Data diolah, 2019 & & 1.249 \\
& & .089 \\
\hline
\end{tabular}


Pada Tabel 2. dapat dilihat bahwa Nilai Kolmogorov-Smirnov sebesar 0,089 dan signifikan pada 0,05 (karena $\mathrm{p}=0,089>0.05$ ). Jadi dapat disimpulkan bahwa residual berdistribusi normal. Suatu model regresi jika mengandung gejala autokorelasi, maka prediksi yang dilakukan dengan model tersebut akan tidak baik, atau dapat memberikan hasil prediksi yang menyimpang. Uji autokorelasi dalam peneitian ini dilakukan dengan Uji Durbin-Watson (DW-test) atau d statistik terhadap variabel pengganggu (disturbance error term).

Tabel 3.

Hasil Uji Autokorelasi

\begin{tabular}{|c|c|c|c|c|c|}
\hline Model & $\mathbf{R}$ & R Square & $\begin{array}{l}\text { Adjusted R } \\
\text { Square }\end{array}$ & $\begin{array}{l}\text { Std. Error of the } \\
\text { Estimate }\end{array}$ & Durbin-Watson \\
\hline 1 & $.356^{\mathrm{a}}$ & .712 & .905 & .356043 & 1.7682 \\
\hline
\end{tabular}

Sumber : Data diolah, 2019

Pada Tampilan Tabel 3. menunjukkan besarnya nilai Durbin Watson sebesar 1,7682. Nilai $\mathrm{D}-\mathrm{W}$ menurut tabel dengan $\mathrm{n}=85$ dan $\mathrm{k}=3$ didapat nilai $\mathrm{dl}=1.6902$ dan nilai $d u=1.7729$. Oleh karena nilai $d u<d<(4-d u) \quad(1.6902<1.7682<1.7729)$, maka dapat disimpulkan tidak terdapat autokorelasi antar residual. Uji multikolinearitas bertujuan untuk menguji apakah pada model regresi ditemukan adanya korelasi antar variabel bebas. Model regresi yang baik seharusnya tidak terjadi korelasi di antara variabel bebas. Untuk mendeteksi adanya masalah multikolineritas dapat dilihat dari nilai tolerance dan nilai variance inflation faktor (VIF).

Tabel 4.

Hasil Uji Multikolinearitas

\begin{tabular}{llll}
\hline & \multicolumn{1}{c}{ Model } & \multicolumn{2}{c}{ Collinearity Statistic } \\
& & Tolerance & VIF \\
\hline 1 & Profitabilitas & 0,014 & 14,666 \\
2 & Kebijakan deviden & 0,083 & 12,082 \\
3 & Profitabilitas- Kebijakan deviden & 0,048 & 20,802 \\
\hline
\end{tabular}

Sumber : Data diolah, 2019

Berdasarkan Tabel 4. dapat dilihat bahwa nilai VIF dan Tolerance, dimana diperlihatkan bahwa tidak terdapat nilai Tolerance yang kurang dari 0,1 ataupun nilai VIF yang lebih tinggi dari 10. Oleh karena itu berdasarkan nilai Tolerance dan VIF pada model analisis tersebut tidak ditemukan adanya gejala multikolinearitas. Uji Heteroskedastisitas dilakukan untuk mengetahui bahwa pada model regresi terjadi ketidaksamaan varian. Untuk mendeteksi ada atau tidaknya Heteroskedastisitas digunakan uji model Glejser. Tabel 5 akan memperlihatkan hasil Uji Glejser untuk mendeteksi ada atau tidaknya Heteroskedastisitas. 
Tabel 5.

Hasil Uji Heteroskedastisitas

\begin{tabular}{lll}
\hline Variabel & Sig. & Keterangan \\
\hline Profitabilitas & 0,209 & Bebas heteroskedastisitas. \\
Kebijakan deviden & 0,065 & Bebas heteroskedastisitas \\
Profitabilitas- Kebijakan deviden & 0,061 & Bebas heteroskedastisitas \\
\hline
\end{tabular}

Sumber : Data diolah, 2019

Tabel 5. diatas diperoleh hasil nilai signifikansi X sebesar 0,209, M sebesar 0,065 , dan XM sebesar 0,061. Hasil uji tersebut memiliki nilai yang lebih besar dari $\alpha=0.05$. Oleh karena itu, dapat disimpulkan bahwa tidak terjadi heteroskedastisitas. Teknik analisis data yang diterapkan dalam penelitian ini dilakukan secara kuantitatif dengan penekanan data yang bersumber dari data primer, yang mana data tersebut akan diolah kemudian dianalisis.

Teknik perhitungan dan analisis data menggunakan Moderating Regression Analysis. Moderating Regression Analysis dinyatakan dalam bentuk regresi berganda dengan persamaan yang menggambarkan kebijakan deviden memoderasi pengaruh profitabilitas terhadap nilai perusahaan pada Indeks Kompas 100 dengan bantuan program Statistical Package of Social Science (SPSS). Hasil pengujian disajikan dalam hasil uji nilai selisih mutlak pada Tabel 6. berikut ini.

Tabel 6.

Hasil Pelaporan Analisis MRA

\begin{tabular}{|c|c|c|c|c|c|}
\hline \multirow[b]{2}{*}{ Variabel } & & \multicolumn{3}{|c|}{ Koefisien Regresi } & \multirow[b]{2}{*}{ Sig } \\
\hline & & B & $\begin{array}{l}\text { Std. } \\
\text { error }\end{array}$ & $\mathbf{t}$ & \\
\hline \multicolumn{2}{|l|}{ (constant) } & 0,147 & 0,250 & 0,587 & 0,559 \\
\hline \multicolumn{2}{|l|}{ Profitabilitas } & 0,355 & 0,114 & 3,118 & 0,003 \\
\hline \multicolumn{2}{|c|}{ Kebijakan deviden } & 0,020 & 0,015 & 1,349 & 0,001 \\
\hline \multicolumn{2}{|c|}{ Profitabilitas - Kebijakan deviden $\mid \mathrm{XM}$} & 0,012 & 0,005 & 2,126 & 0,037 \\
\hline Dependen variabel & : Nilai peru & & & & \\
\hline F Statistik & : 3.923 & & & & \\
\hline Sig F & : 0.011 & & & & \\
\hline $\mathrm{R}^{2}$ & $: 0.712$ & & & & \\
\hline
\end{tabular}

Persamaan regresi pada Tabel 6, dapat dijelaskan untuk setiap variabel halhal sebagai berikut:

$$
\mathrm{Y}=0,147+0,355 \mathrm{X}+0,020 \mathrm{M}+0,012|\mathrm{XM}|
$$

Nilai konstanta sebesar 0,147 menunjukan bahwa bila profitabilitas (X), kebijakan deviden (M) sama dengan nol, maka nilai perusahaan (Y) konstant sebesar 0,147 satuan. Nilai Koefisien $\beta_{1}$ yang diperoleh sebesar 0,355 menunjukan bahwa interaksi antara variabel profitabilitas dan nilai perusahaan bersifat positif. Artinya interaksi profitabilitas berpengaruh terhadap nilai perusahaan pada perusahaan Indeks Kompas 100. Nilai Koefisien $\beta_{2}$ yang diperoleh sebesar 0,020 menunjukan bahwa interaksi antara variabel kebijakan deviden dan nilai perusahaan bersifat positif. Artinya interaksi kebijakan deviden berpengaruh terhadap nilai perusahaan pada perusahaan Indeks Kompas 100. Nilai Koefisien $\beta_{3}$ 
yang diperoleh sebesar 0,012 menunjukan bahwa interaksi antara variabel profitabilitas dan kebijakan deviden bersifat positif. Artinya interaksi kebijakan deviden memoderasi pengaruh profitabilitas terhadap nilai perusahaan pada perusahaan Indeks Kompas 100.

Hasil uji statistik F pada Tabel 6, menunjukan hasil nilai siginifikansi sebesar 0,000 yang lebih kecil dari tingkat $\alpha=0,05$. Hal ini profitabilitas dan kebijakan deviden secara bersama berpengaruh signifikan terhadap nilai perusahaan pada perusahaan Indeks Kompas 100. Hal ini mengindikasikan bahwa model yang digunakan dalam penelitian ini layak dipergunakan. Hasil perhitungan uji t dapat dilihat pada Tabel 6. Dari tabel tersebut diketahui bahwa nilai thitung variabel $\mathrm{X}$ adalah sebesar 3,118 dengan tingkat signifikansi sebesar 0,003 lebih kecil dibandingkan dengan taraf nyata $\alpha=0,05$. Hal ini menunjukan bahwa profitabilitas berpengaruh positif dan signifikan terhadap nilai perusahaan pada perusahaan Indeks Kompas 100. Semakin tinggi profitabilitas maka nilai perusahaan juga semakin meningkat. Berdasarkan penjelasan tersebut dapat disimpulkan bahwa hipotesis pertama diterima.

Hasil perhitungan uji $\mathrm{t}$ dapat dilihat pada Tabel 6. Dari tabel tersebut diketahui bahwa nilai thitung variabel $X$ adalah sebesar 1,349 dengan tingkat signifikansi sebesar 0,001 lebih kecil dibandingkan dengan taraf nyata $\alpha=0,05$. Hal ini menunjukan bahwa kebijakan deviden berpengaruh positif dan signifikan terhadap nilai perusahaan pada perusahaan Indeks Kompas 100. Semakin baik kebijakan deviden yang dihasilkan maka nilai perusahaan juga semakin meningkat. Berdasarkan penjelasan tersebut dapat disimpulkan bahwa hipotesis kedua diterima. Hasil perhitungan uji t dapat dilihat pada Tabel 6. Dari tabel tersebut diketahui bahwa nilai thitung $|\mathrm{XM}|$ adalah sebesar 2,126 dengan tingkat signifikansi sebesar 0,037 lebih kecil dibandingkan dengan taraf nyata $\alpha=0,05$. Hal ini menunjukan bahwa kebijakan deviden memoderasi pengaruh positif profitabilitas terhadap nilai perusahaan pada perusahaan Indeks Kompas 100, artinya semakin baik kebijakan deviden maka semakin meningkatnya profitabilitas perusahaan sehingga mampu meningkatkan nilai perusahaan pada perusahaan Indeks Kompas 100. Berdasarkan penjelasan tersebut, dapat disimpulkan bahwa hipotesis ke tiga diterima.

Pengujian koefisien determinasi $\left(\mathrm{R}^{2}\right)$ dilakukan untuk mengetahui seberapa besar variasi variabel dependent akan mampu dijelaskan oleh variabel independennya, sedangkan sisanya dijelaskan oleh sebab-sebab variabel lain di luar model (Ghozali, 2011:97). Berdasarkan Tabel 6. menunjukan bahwa nilai adjusted $\mathrm{R}$ square model 0,712 atau sebesar 71,2 persen artinya sebesar 71,2 persen variasi nilai perusahaan pada perusahaan Indeks Kompas 100 dapat dijelaskan oleh variasi variabel dalam model tersebut yaitu profitabilitas dan kebijakan deviden.

Hasil analisis menunjukan bahwa profitabilitas berpengaruh positif dan signifikan terhadap nilai perusahaan pada perusahaan Indeks Kompas 100. Berdasarkan Signalling Theory, merupakan informasi mengenai perusahaan merupakan sinyal bagi investor, dalam keputusan berinvestasi. Hasilnya, investor dapat melihat seberapa efisien perusahaan menggunakan aset dan dalam melakukan operasinya untuk menghasilkan keuntungan, sehingga profitabilitas akan meningkatkan nilai perusahaan, profitabilitas perusahaan sangatlah penting karena 
untuk dapat melangsungkan kegiatan operasionalnya, profitabilitas adalah gambaran dari nilai perusahaan, nilai perusahaan yang tinggi menunjukkan kinerja perusahaan yang baik.

Beberapa penelitian seperti penelitian (Mery, 2017) menyatakan profitabilitas secara langsung memiliki pengaruh positif terhadap nilai perusahaan. (Sisca, 2016) membuktikan profitabilitas memiliki pengaruh positif dalam meningkatkan nilai perusahaan. (Alamsyah, 2017) menyatakan peningkatan profitabilitas memiliki pengaruh positif terhadap nilai perusahaan. (Tahu \& Susilo, 2017) membuktikan hal yang sama dimana profitabilitas memiliki pengaruh positif dalam meningkatkan nilai perusahaan.

Hasil analisis menunjukan bahwa kebijakan deviden berpengaruh positif dan signifikan terhadap nilai perusahaan pada perusahaan Indeks Kompas 100. Berdasarkan signalling theory, kebijakan dividen sering dianggap sebagai signal bagi investor dalam menilai baik buruknya perusahaan, hal ini disebabkan karena kebijakan dividen dapat membawa pengaruh terhadap harga saham perusahaan (Weston dan Copeland , 2013). Apabila dividen yang dibayarkan tinggi maka harga saham cenderung tinggi sehingga nilai perusahaan juga tinggi. Namun, jika dividen yang dibayarkan kepada pemegang saham kecil akan berakibat pada harga saham perusahaan menjadi rendah. Dengan demikian, dividen yang besar akan meningkatkan nilai perusahaan. Hal ini menunjukkan bahwa jika dividen meningkat maka nilai perusahaan akan meningkat, karena dividen yang tinggi akan menyebabkan menguatnya dana external perusahaan, sehingga kinerja perusahaan juga meningkat yang mengakibatkan naiknya nilai perusahaan.

Beberapa penelitian seperti penelitian (Diani, 2015) menyatakan kebijakan dividen berpengaruh terhadap nilai perusahaan. (Burhanudin \& Nuraini, 2018) menyatakan kebijakan dividen secara positif berpengaruh terhadap nilai perusahaan. (Mery, 2017) menyatakan kebijakan dividen berpengaruh positif terhadap nilai perusahaan. (Sisca, 2016) menyatakan kebijakan dividen secara positif berpengaruh terhadap nilai perusahaan.

Hasil analisis menunjukan bahwa kebijakan deviden memoderasi pengaruh positif dan signifikan profitabilitas terhadap nilai perusahaan pada perusahaan Indeks Kompas 100. Kebijakan dividen bertindak sebagai moderasi yang memperkuat pengaruh profitabilitas terhadap nilai perusahaan. Berdasarkan signalling theory menyatakan profitabilitas yang tinggi serta kebijakan dividen yang optimal mampu mencerminkan prospek perusahaan yang bagus sehingga dapat menaikkan harga saham serta meningkatkan nilai perusahaan (Mery, 2017).

Hasil penelitian ini sama dengan penelitian (Burhanudin \& Nuraini, 2018) menyatakan kebijakan dividen memoderasi pengaruh positif profitabilitas terhadap nilai perusahaan. (Sisca, 2016) menyatakan sebagai variabel moderasi kebijakan dividen mampu memperkuat pengaruh profitabilitas terhadap nilai perusahaan secara positif. (Diani, 2015) menyatakan kebijakan dividen mampu memoderasi pengaruh positif profitabilitas terhadap nilai perusahaan. (Mery, 2017) menyatakan profitabilitas berpengaruh positif terhadap nilai perusahaan diperkuat atau dimoderasi oleh variabel kebijakan dividen. Menjawab manfaat penelitian, maka dapat dijabarkan hubungan kausal antar variabel kebijakan deviden memoderasi 
pengaruh profitabilitas terhadap nilai perusahaan pada perusahaan Indeks Kompas 100 sebagai berikut.

Hasil penelitian ini memberi dampak terhadap investor untuk dapat mengambil keputusan dalam melakukan investasi dengan mempertimbangkan kinerja perusahaan dan kebijakan dividen. Bagi perusahaan dapat mengambil keputusan untuk mengambil kebijakan dalam menentukan seberapa besar laba perusahaan yang dapat diberikan kepada investor atau ditahan membuat perusahaan bisa menyimpan laba dan kas perusahaan. Dana tersebut bisa digunakan perusahaan untuk tujuan yang lain. Seperti pengembangan usaha, pembayaran utang yang segera jatuh tempo atau digunakan untuk pembayaran hal yang lain.

Pembayaran dividen menunjukkan bahwa perusahaan tersebut memiliki kinerja perusahaan yang baik. Dividen payout ratio yang tinggi akan memperkuat pengaruh profitabilitas terhadap nilai perusahaan. Manfaat bagi pemegang saham kebijakan dividen adalah keputusan keuangan, yang akan meningkatkan kemakmuran pemegang saham. Bagi perusahaan besarnya dividen dapat mempengaruhi harga saham yang cenderung tinggi sehingga nilai perusahaan juga tinggi.

\section{SIMPULAN}

Berdasarkan pada hasil analisis data dan pembahasan yang telah dipaparkan pada bab sebelumnya, maka dapat ditarik kesimpulan sebagai berikut: Profitabilitas secara signifikan berpengaruh positif terhadap nilai perusahaan. Ini berarti setiap peningkatan profitabilitas akan menentukan nilai perusahaan. Kebijakan deviden secara signifikan berpengaruh positif terhadap nilai perusahaan. Pengaruh kebijakan deviden mampu memperkuat nilai perusahaan di mata investor. Kebijakan deviden memoderasi pengaruh profitabilitas terhadap nilai perusahaan. Kebijakan deviden yang ditetapkan menunjukkan meningkatnya profitabilitas perusahaan sehingga meningkatkan nilai perusahaan di mata investor.

Perusahaan pada Indeks Kompas 100 disarankan agar meningkatkan kinerja perusahaan yang tercermin dari besarnya ROA, dan pembayaran dividen yang dilakukan oleh perusahaan tiap tahunnya agar mampu bersaing dalam memperoleh kepercayaan investor, sehingga memudahkan untuk memperoleh modal dari luar perusahaan. Profitabilitas merupakan rasio yang menggambarkan kemampuan perusahaan dalam menghasilkan laba. Semakin baik rasio profitabilitas maka semakin baik menggambarkan kemampuan tingginya perolehan keuntungan perusahaan.

Perusahaan pada Indeks Kompas 100 disarankan memperhatikan kebijakan dividen sebagai keputusan keuangan, yaitu dengan mempertimbangkan apakah pembayaran dividen akan meningkatkan kemakmuran pemegang saham. Adanya peran kebijakan deviden terhadap saham perusahaan, karena kebijakan dividen mampu meningkatkan nilai perusahaan pada saat profitabilitas tinggi. Bagi peneliti selanjutnya sebaiknya menambah rasio keuangan lain sebagai variabel independen, karena dapat dimungkinkan masih ada rasio keuangan lain yang dapat mempengaruhi nilai perusahaan. Peneliti juga dapat menambah jumlah sampel 
yang digunakan untuk memperpanjang periode pengamatan agar didapat hasil peneliti yang beragam.

\section{REFERENSI}

Ajanthan, A. (2013). Corporate Governance and Dividend Policy: a Study of Listed Hotls and Restaurant Companies in Sri Lanka. International Journal of Scientific \& Research Publications, 3(12), 98-114.

Alamsyah, S. (2017). PENGARUH PROFITABILITAS TERHADAP NILAI PERUSAHAAN, RELEVANSI NILAI INFORMASI AKUNTANSI, KEPUTUSAN INVESTASI, KEBIJAKAN DIVIDEN SEBAGAI VARIABEL INTERVENING (Studi Empiris Pada Perusahaan Indeks Kompas 100 Periode 2010-2013). Competitive Jurnal Akuntansi Dan Keuangan, 1(1), 136. https://doi.org/10.31000/competitive.v1i1.112

Andawasatya, R., Indrawati, N. K., \& Aisjah, S. (2017). The Effect of Growth Opportunity, Profitability, Firm Size to Firm Value through Capital Structure (Study at Manufacturing Companies Listed On the Indonesian Stock Exchange). Imperial Journal of Interdisciplinary Research, 3(2), 1887-1894. Retrieved from http://www.onlinejournal.in

Aries, H. P. (2011). Valuasi Perusahaan (Cetakan I). Jakarta: Penerbit PPM.

Arthur J. Keown. (2011). Dasar-Dasar Manajemen Keuangan (Kedua). Jakarta: Salemba Empat.

Borges Forti, C. A., Peixoto, F. M., \& Lima E Alves, D. (2015). Determinant factors of dividend payments in Brazil. Revista Contabilidade e Financas, 26(68), 167-180. https://doi.org/10.1590/1808-057x201512260

Brigham, E. F., \& Joel F. Houston. (2011). Fundamentals of Financial Management (Ninth Edit). United States of America: Horcourt College.

Burhanudin, \& Nuraini. (2018). PENGARUH STRUKTUR MODAL DAN PROFITABILITAS TERHADAP NILAI PERUSAHAAN DENGAN KEBIJAKAN DIVIDEN SEBAGAI VARIABEL PEMODERASI BURHANUDIN. Eco-Entrepreneurship, 3(2), 21-36.

Cheryta, A. M., Moeljadi, \& Indrawati, N. K. (2017). The Effect of Leverage, Profitability, Information Asymmetry, Firm Size on Cash Holding and Firm Value of Manufacturing Firms Listed at Indonesian Stock Exchange. International Journal of Research in Business Studies and Management, 4(4), 21-31. https://doi.org/10.22259/ijrbsm.0404004 
Diani, A. F. (2015). PENGARUH KEBIJAKAN DIVIDEN, KEBIJAKAN HUTANG DAN PROFITABILITAS TERHADAP NILAI PERUSAHAAN (Studi Kasus Pada Perusahaan Consumer Goods Yang Terdaftar Di Bursa Efek Indonesia Periode Tahun 2012-2015). E-Jurnal Riset Manajemen.

Ghalandari, K. (2013). The moderating effects of growth opportunities on the relationship between capital structure and dividend policy and ownership structure with firm value in iran: Case study of tehran securities exchange. Research Journal of Applied Sciences, Engineering and Technology, 5(4), 1424-1431. https://doi.org/10.19026/rjaset.5.4883

Ghozali, I. (2016). Aplikasi Analisis Multivariate dengan Program IBM SPSS (Kelima). Semarang: universitas Diponegoro.

Gumanti, T. A. (2013). Kebijakan Dividen Teori Empiris dan Implikasi (Pertama). Yogyakarta: UPP STIM YKPN.

Hanafi. (2015). Manajemen Keuangan. Yogyakarta: BPFE UGM.

Harnanto. (2012). Akuntansi Keuangan Menengah (BPFE, ed.). Yogyakarta.

Labhane, N. B., \& Das, R. C. (2015). Determinants of Dividend Payout Ratio: Evidence from Indian Companies. Business and Economic Research, 5(2), 217. https://doi.org/10.5296/ber.v5i2.8154

Mery, K. N. (2017). The Effect of Liquidity, Leverage and Profitability of the Corporate's Value with Dividend Policy as Moderation on Mining Companies at The Indonesia Stock Exchange Year 2011-2014. Jurnal Online Mahasiswa (JOM) Bidang Akuntansi, 4(1), 2000-2014.

Mirah, A. A. A., Devi, V., \& Suardikha, I. M. S. (2014). KEBIJAKAN DIVIDEN DENGAN LIKUIDITAS SEBAGAI VARIABEL PEMODERASI Fakultas Ekonomi Universitas Udayana ( Unud ), Bali, Indonesia Fakultas Ekonomi Universitas Udayana ( Unud), Bali, Indonesia Email : ayumirah_devi@yahoo.co.id Salah satudaya tarik berinve. 12, 702-717.

Murukefu, T. M., \& Ouma, O. P. (2017). The Relationship Between Dividend Payout and Firm Performance: A Study of Listed Companies in Kenya. European Scientific Journal, ESJ, 8(9), 119-215.

Napa J. Awat. (2000). Manajemen Keuangan. Jakarta: Gramedia Pustaka Utama.

Natalia, D. (2013). Pengaruh Profitabilitas Dan Kesempatan Investasi Terhadap Kebijakan Dividen Pada Perusahaan Manufaktur Yang Terdaftar Di Bei. Jurnal Akuntansi, 1(1), 1-20. 
Puspitaningtyas, Z. (2017). Efek Moderasi Kebijakan Dividen Dalam Pengaruh Profitabilitas Terhadap Nilai Perusahaan. JURNAL AKUNTANSI, EKONOMI DAn MANAJEMEN BISNIS, 5(2), 173.

https://doi.org/10.30871/jaemb.v5i2.538

Setiyawati, L., Wahyudi, S., \& Mawardi, W. (2018). THE INFLUENCE OF DIVIDEND POLICY, DEBT POLICY, INDEPENDENT COMMISSIONER, AND INSTITUTIONAL OWNERSHIP ON THE FIRM VALUE WITH GROWTH OPPORTUNITIES AS MODERATOR VARIABLES (Study on Non-Financial Companies Listed on IDX in the Period of Years of 2012-2015). Jurnal Bisnis Strategi, 26(2), 146. https://doi.org/10.14710/jbs.26.2.146-162

Setyowati, T. (2014). PENGARUH PROFITABILITAS, KEBIJAKAN DIVIDEN, DAN CORPORATE SOCIAL RESPONSIBILITY (CSR) TERHADAP NILAI PERUSAHAAAN. Jurnal Akuntansi UMS.

Sisca. (2016). Pengaruh Leverage dan Profitabilitas terhadap Nilai Perusahaan pada perusahaan manufaktur yang terdaftar di Bursa Efek Indonesia dengan Kebijakan Dividen sebagai variabel moderating Pada Perusahaan Manufaktur yang terdaftar di Bursa Efek Indonesia Tahun 2. Jurnal Sultanist Manajemen Dan Keuangan, 4(1), 1-9.

Suad Husnan. (2015). Dasar-Dasar Manajemen Keuangan (Empat). Yogyakarta: UPP AMP YKPN.

Sucuahi, W., \& Cambarihan, J. M. (2016). Influence of Profitability to the Firm Value of Diversified Companies in the Philippines. Accounting and Finance Research, 5(2). https://doi.org/10.5430/afr.v5n2p149

Sundari, T. W., \& Utami, W. (2013). PENGARUH KINERJA KEUANGAN TERHADAP NILAI PERUSAHAAN DENGAN KEBIJAKAN DIVIDEN. Jurnal Mix, 3(3), 309-321. https://doi.org/10.1017/CBO9781107415324.004

Suteja, J., \& Abas, M. R. (2018). Factor Influence Analysis of Corporate Value with Firm Size As Moderator Variable in Indonesia Stock Exchange. Ekuilibrium : Jurnal Ilmiah Bidang Ilmu Ekonomi, 13(1), 57. https://doi.org/10.24269/ekuilibrium.v13i1.916

Tahu, G. P., \& Susilo, D. D. B. (2017). Effect of Liquidity , Leverage and Profitability to The Firm Value (Dividend Policy as Moderating Variable) in Manufacturing Company of Indonesia Stock Exchange. Research Journal of Finance and Accounting, 8(18), 89-98.

Teguh, P., \& Ardianto. (2015). The moderating effect of growth opportunities on the relationship between financing decision, dividend policy, profitability 
E-Jurnal Manajemen, Vol. 9, No. 2, 2020 : 658-677

and liquidity toward firm value. 18.

Triana, D., \& Istyana, A. N. (2017). Pengaruh Profitabilitas Terhadap Nilai Perusahaan dengan Zakat sebagai Variabel Pemoderasi. Jurnal Proceeding National, 3(2), 87-92.

Yulandani, F., Hartanti, R., \& Dwimulyani, S. (2018). Pengaruh Profitabilitas Dan Ukuran Perusahaan Terhadap Nilai Perusahaan Dengan Csr Sebagai Pemoderasi. Proseding Seminar Nasional Akuntansi, 1, 1-14. 